\title{
Contact Dermatitis caused by 2-HEMA and GM Dentin Primer Solutions applied to Guinea Pigs and Humans
}

\author{
Kazuyuki KATSUNO, Atsufumi MANABE, Kazuo ITOH, Yoshihiro NAKAMURA, \\ Sadao WAKUMOTO, Hisashi HISAMITSU and Takemi YOSHIDA ${ }^{1}$ \\ Department of Operative Dentistry, School of Dentistry, Showa University, \\ 2-1-1 Kitasenzoku, Ohta-ku, Tokyo 145, Japan \\ ${ }^{1}$ Department of Biochemical Toxicology, School of Pharmaceutical Sciences, Showa University, \\ 1-5-8 Hatanodai, Shinagawa-ku, Tokyo 142, Japan
}

Received January 22, 1996/Accepted April 18, 1996

\begin{abstract}
The purposes of this study were to examine whether 2-HEMA, GM, and methacrylic acid cause contact dermatitis, and to determine the optimum concentrations of these primers for sensitization and challenge in guinea pigs. A sensitizing concentration of $0.2 \%$ 2-HEMA resulted in strong rubefaction and several vesiculopapules in response to the challenge, and a sensitizing concentration of $0.5 \% \mathrm{GM}$ produced strong rubefaction at 24 hours. We also observed the development of contact dermatitis on human brachia in a closed-patch test. Skin that was treated with both 2-HEMA and GM clearly showed the onset of rubefaction and itchiness. 2-HEMA caused sensitized delayed allergic reactions at all the concentrations tested.
\end{abstract}

Key words : 2-hydroxyethyl methacrylate (2-HEMA), Glyceryl methacrylate (GM), Allergic contact dermatitis

\section{INTRODUCTION}

In restoration with composite resins, dentin primers are applied prior to dentin bonding agents to obtain complete marginal adaptation between the dentin and the composite resins. We previously suggested that 2-hydroxyethyl methacrylate (2-HEMA) ${ }^{1-3)}$, glyceryl methacrylate $(\mathrm{GM})^{4)}$ and erythritol methacrylate $(\mathrm{EM})^{5}$ prevent the formation of gaps between the dentin cavity margin and the polymerzed composite resin. It is widely accepted that methacrylate derivatives are indispensable components of dentin primers when used as dentin adhesives. However, Waegemaekers et al. and Pegum and Medhurst reported that surgical gloves are permeable to methyl mathacrylate monomer ${ }^{6,7)}$. Therefore, even if the dentist tries to protect his or her fingers from methacrylates by wearing rubber gloves, rubefaction, tumefaction, blebs, and pruritus can occur on the fingertips. Furthermore, Mathias et al. reported that nausea and diarrhea can occur with severe allergic contact dermatitis due to 2-HEMA, and that these gastrointestinal conditions can be reproduced by conducting patch tests on people allergic to 2-HEMA ${ }^{8}$. Hayakawa $e t$ al. reported two cases of occupational contact dermatitis suspected to have been caused by contact with 2-HEMA ${ }^{9)}$. In addition, Malten and Bende reported contact sensitizers in a photopolymer printing plate procedure ${ }^{10}$. In a study conducted on animals, Van der Walle et al. showed that mono (meth) acrylate is more potent in its ability to sensitize guinea pigs than are other monomers ${ }^{11)}$.

In experiments on dentin bonding systems, including the application of a dentin primer 
(i.e., 2-HEMA and GM) in vitro, we used extracted human teeth. The teeth were gripped between the thumb, forefinger, and middle finger of the left hand. A primer was then applied to the dentin surface and dried by a gentle stream of air. However, this would often cause the primer to splatter onto the fingers of the left hand. One of our colleagues was sensitized with a primer and experienced contact dermatitis. In previous studies, we showed that the 2-HEMA solution had an inflammatory effect, while neither the 2-HEMA nor the GM solution caused any immediate allergic reaction in guinea pigs ${ }^{12-15)}$. Methacrylate derivatives have been shown to produce type IV allergic reactions on human skin. However, we have been unable to produce a type $\mathrm{IV}$ allergic reaction on animal skin because these monomers have low molecular weights. Furthermore, it is still unclear whether there is still some optimum concentration of methacrylate derivatives for sensitizing guinea pigs.

The present study was undertaken to examine whether contact dermatitis develops and, using a maximization test, to determine the optimum concentrations of 2-HEMA, GM, and methacrylic acid (MA) for sensitization and challenge in guinea pigs. We also observed the development of contact dermatitis on human brachia in a colsed-patch test.

\section{MATERIALS AND METHODS}

\section{Materials}

The dentin primers investigated in this study were 2-HEMA*, GM** and $\mathrm{MA}^{\# 1-4,15)}$. 3-4 dichloronitrobenzene ${ }^{\sharp}$ was used as a positive control and distilled water as a negative control. Various concentrations of the methacrylic derivatives were used to determine the optimum concentration for sensitization and elication (Tables 1 and 2). All of the derivatives were diluted with olive oil\# and acetone ${ }^{\#}(7: 3 \mathrm{v} / \mathrm{v})$. The concentrations of 2-HEMA and GM were $0.01,0.02,0.1,0.2,0.5,1.0$, and $5.0 \%$. The concentrations of MA were $0.02,0.1,0.2,0.5,1.0$, and $5.0 \%$. The various concentrations of 2 -HEMA, GM, and MA were tested on five animals each.

The solution for injection was prepared by mixing equal volumes of Freund's complete adjuvant (FCA)\#\# and distilled water using two 5-ml glass syringes and a stainless steel syringe connector.

Table 1 Methacrylic derivatives used as sensitizers

\begin{tabular}{lc}
\multicolumn{1}{c}{\begin{tabular}{c}
\multicolumn{1}{c}{$\begin{array}{c}\text { Sample solutions } \\
\text { (Code) }\end{array}$} \\
\multicolumn{1}{c}{$\begin{array}{c}\text { Sensitization concentration } \\
(\%)\end{array}$} \\
\hline $\begin{array}{l}\text { 2-Hydroxyethyl methacrylate } \\
\text { (2-HEMA) }\end{array}$
\end{tabular}} & $0.01,0.02,0.1,0.2,0.5,1.0,5.0$ \\
$\begin{array}{l}\text { Glyceryl methacrylate } \\
\text { GM) }\end{array}$ & $0.01,0.02,0.1,0.2,0.5,1.0,5.0$ \\
\hline
\end{tabular}

For sensitization the sample solutions were diluted with a mixture of olive oil and acetone $(7: 3 \mathrm{v} / \mathrm{v})$

* Merck A. G., Darmstad, Germany

** Nippon Oil and Fat, Tokyo, Japan

\# Wako Co., Ltd., Osaka, Japan

\# Difco Laboratories, Michigan, USA 
Table 2 Methacrylic derivatives used in elicitation

\begin{tabular}{lll}
\hline \multicolumn{1}{c}{ Sample solutions } & \multicolumn{1}{c}{ Code } & Induction (\%) \\
\hline 2-Hydroxyethyl methacrylate & $(2-\mathrm{HEMA})$ & $10,25,50,100$ \\
Glyceryl methacrylate & $(\mathrm{GM})$ & $10,25,50,100$ \\
Methacrylic acid & (MA) & $10,25,50,100$ \\
3, 4-dichloronitrobenzene & (DCNB) & $10,25,50,100$ \\
(Positive control) & & \\
\hline
\end{tabular}

For induction the sample solutions were applied to guinea pigs.

\section{Guinea pig maximization test}

1) Determination of optimum concentrations of 2-HEMA, GM, and MA for sensitization. This test was performed according to the method of Magnusson and Kligman ${ }^{16)}$. A total of 105 female Hartley guinea pigs, each weighing 300-500g, were used. The animals were housed singly in stainless steel wire-mesh cages in a room kept at a constant temperature of $23 \pm 2^{\circ} \mathrm{C}$ and a relative humidity of $55 \pm 5 \%$. The experiments were carried out under Showa University's Guidelines for the Practice of Animal Care and Experiments and were supervised by the university's Committee on Animal Experiments.

Induction was performed in two stages. Inductions were firstly made in a $4 \times 6 \mathrm{~cm}$ clipped and shaved area of back near the neck. In the first stage of induction, $50 \mu 1$ of each experimental test substance solution was injected into the back near the neck. An aqueous mixture of FCA, the experimental test substance alone, and a mixture of the test substance and FCA were each injected into two sites (three injections per side, six injections in total). One week later, at the second stage of induction, the guinea pigs were pretreated with $10 \%$ sodium lauryl sulfate in petrolatum for 24 hours. We then placed a filter paper ${ }^{\circledR}$ patch that had been soaked in $200 \mu$ l of test substance on the shaved back of the guinea pig. The patch was held in place by impermeable plastic adhesive tape ${ }^{\circledR}$ for 48 hours. The challenge test was carried out by topical application of the primer on day 22. Hair was again clipped and shaved from the flank. The test substances were applied to the skin by the closed-patch testing technique ${ }^{17)}$. The test substance $(100 \mu 1$, undiluted) was used as a challenge vehicle. In reading challenge reactions, the challenge site was evaluated 24 hours after removal of the filter paper and adhesive tape.

2) Determination of the optimum concentrations of 2-HEMA, GM, and MA for elicitation. Based on the results of the sensitization experiment, $0.2 \%$ concentrations of 2-HEMA, GM, and MA were used in the elicitation test ${ }^{16}$. The challenge concentrations were $10,25,50$, and $100 \%$. The challenge primers were applied at four points on each animal. Five animals were used in each group (2-HEMA, GM, and MA) in this experiment.

The skin reaction was evaluated according to the criteria of the International Contact Dermatitis Research Group (ICDRG) ${ }^{18)}$ (Table 3).

\section{The patch test on humans}

A 30-year-old male dentist had been using 2-HEMA as a dentin primer for three years.

@ Toyo Roshi Co., Tokyo, Japan

@@ Blenderm, 3M Co., Ltd., Tokyo, Japan 
During that time he had never experienced inflammation or pruritus of the fingertips. However, one day he showed clinical symptoms soon after he had touched 2-HEMA solution. Since then he has experienced allergic reactions such as redness, pruritus, sclerosis, and edema on his fingertips whenever he has handled a 2-HEMA solution. When such symptoms appeared, a dermatologist at Showa University hospital diagnosed him with contact dermatitis and suspected an allergic reaction based on the anamnesis. Therefore, a patch test was conducted on the dentist. He gave his informed consent to such a test using 2-HEMA and GM solutions. Small squares of white cotton cloth ${ }^{\S}$ soaked with the primers were applied directly to his normally healthy brachial skin and covered with cellophane ${ }^{\$}$. The applications were held in place by adhesive tape $\$$. Following the suggestions of the dermatologist, the concentration of allergen were determined as shown in Table 4. The area of application was kept covered for 48 hours to promote penetration and allow time for a delayed reaction to develop. After 48 hours, the tape and test substances were removed. The results of the test were evaluated using a scale for scoring skin reactions ${ }^{18}$. The negative control was a volunteer who had no history of sensitivity to dentin primers. The patch test was conducted on this individual as described above.

Table 3 Evalution of skin reaction (scale for scoring)

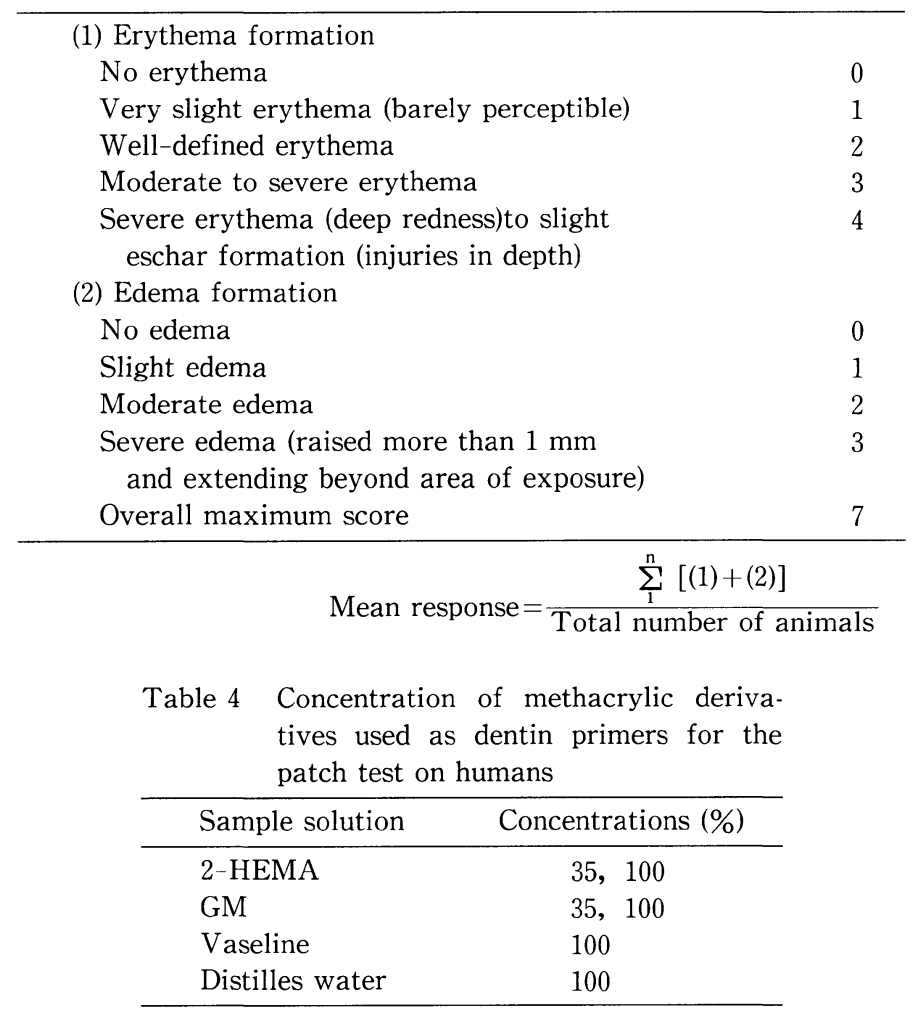

\footnotetext{
\$ Torii, Co., ToKyo, Japan

$\$ \$$ Alcare, Co., Ltd., Tokyo, Japan
} 


\section{RESULTS}

Guinea pig maximization test

1) Determination of optimum concentrations of 2-HEMA, GM, and MA for sensitization. The results of the experiments for determining the optimum concentrations of 2-HEMA, GM, and MA for sensitization are shown in Tables 5, 6 and 7. At 24 hours after patch removal, all the guinea pigs that had been sensitized by various concentrations of 2-HEMA responded to $100 \% 2$-HEMA with allergic reactions. In particular, the $0.2 \%$ concentration resulted in the development of strong rubefaction and several vesiculopapules (mean response : 5.0) (Fig. 1).

In contrast, guinea pigs that had been sensitized by GM at concentrations of 0.01 and $0.02 \%$ did not respond to the challenge dose of the dentin primer at either 24 or 48 hours.

Table 5 Results by concentration with 2-HEMA as a sensitizer

\begin{tabular}{ccccc}
\hline $\begin{array}{c}\text { Concentration } \\
(\%)\end{array}$ & \multicolumn{2}{c}{ Pos./Total } & \multicolumn{2}{c}{ Mean response } \\
$24 \mathrm{~h}$ & $48 \mathrm{~h}$ & $24 \mathrm{~h}$ & $48 \mathrm{~h}$ \\
\hline 0.01 & $4 / 5$ & $2 / 5$ & 1.3 & 1.3 \\
0.02 & $2 / 5$ & $1 / 5$ & 3.8 & 1.3 \\
0.1 & $3 / 5$ & $1 / 5$ & 2.5 & 1.3 \\
0.2 & $5 / 5$ & $5 / 5$ & 5.0 & 5.0 \\
0.5 & $2 / 5$ & $2 / 5$ & 3.8 & 2.5 \\
1.0 & $3 / 5$ & $2 / 5$ & 3.8 & 1.3 \\
5.0 & $2 / 5$ & $1 / 5$ & 1.3 & 1.3 \\
\hline
\end{tabular}

Table 6 Results by concentration with GM as a sensitizer

\begin{tabular}{ccccl}
\hline $\begin{array}{c}\text { Concentration } \\
(\%)\end{array}$ & \multicolumn{2}{c}{ Pos./Total } & \multicolumn{2}{c}{ Mean response } \\
$24 \mathrm{~h}$ & $48 \mathrm{~h}$ & $24 \mathrm{~h}$ & $48 \mathrm{~h}$ \\
\hline 0.01 & $0 / 5$ & $0 / 5$ & 0 & 0 \\
0.02 & $0 / 5$ & $0 / 5$ & 0 & 0 \\
0.1 & $2 / 5$ & $2 / 5$ & 1.3 & 1.3 \\
0.2 & $5 / 5$ & $4 / 5$ & 3.8 & 2.5 \\
0.5 & $5 / 5$ & $5 / 5$ & 6.2 & 5.0 \\
1.0 & $3 / 5$ & $2 / 5$ & 3.8 & 3.8 \\
5.0 & $2 / 5$ & $1 / 5$ & 1.3 & 1.3 \\
\hline
\end{tabular}

Table 7 Results by concentration with MA as a sensitizer

\begin{tabular}{ccccc}
\hline $\begin{array}{c}\text { Concentration } \\
(\%)\end{array}$ & \multicolumn{2}{c}{ Pos./Total } & Mean response \\
$24 \mathrm{~h}$ & $48 \mathrm{~h}$ & $24 \mathrm{~h}$ & $48 \mathrm{~h}$ \\
\hline 0.02 & $4 / 5$ & $4 / 5$ & 6.2 & 6.2 \\
0.1 & $5 / 5$ & $5 / 5$ & 7.0 & 7.0 \\
0.2 & $5 / 5$ & $5 / 5$ & 7.0 & 7.0 \\
0.5 & $5 / 5$ & $5 / 5$ & 7.0 & 7.0 \\
1.0 & $5 / 5$ & $5 / 5$ & 7.0 & 7.0 \\
5.0 & $5 / 5$ & $5 / 5$ & 7.0 & 7.0 \\
\hline
\end{tabular}


The animals did respond to the challeng of GM at concentrations ranging from 0.1 to $1.0 \%$. The $0.5 \%$ concentration produced strong rubefaction (mean response : 6.2 ) at 24 hours (Fig. 2).

All of the concentrations of MA resulted in strong rubefaction and scab formation ${ }^{18)}$. It was difficult to determine whether these were type IV reactions or simple irritation (Fig. 3). All of the guinea pigs sensitized by the various concentrations of MA responded markedly, with scores of 7 on a 7 -point scale. 2-HEMA sensitized guinea pigs more strongly than did

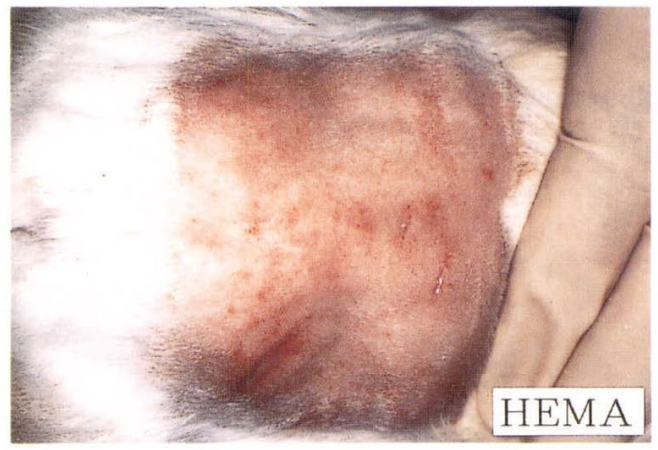

Fig. 1 The challenge reaction was induced by 100\% 2-HEMA after 24 hours. Rubefaction and blebs, approximately $1 \mathrm{~cm}$ in diameter, erupted on the skin of the guinea pig.

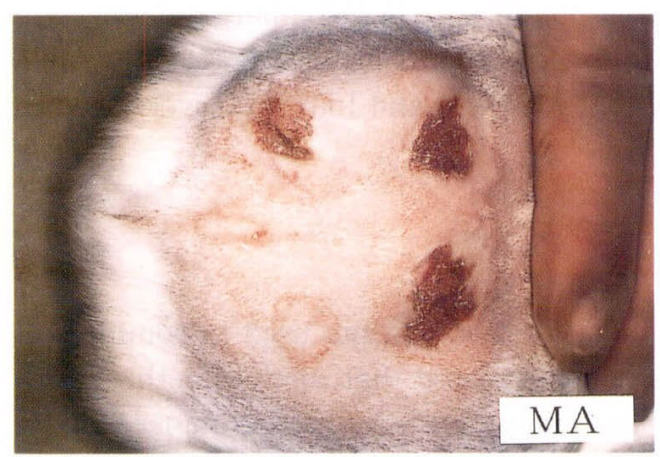

Fig. 3 The challenge reaction was induced by 10 , 25,50 , and $100 \%$ MA after 24 hours. The degree of rubefaction and scab formation depended on the concentration of MA.

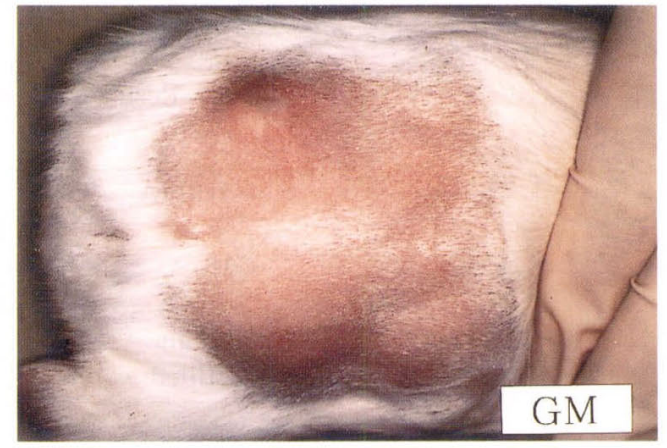

Fig. 2 The challenge reaction was induced by 100\% GM after 24 hours. Two blebs and diffused rubefaction appeared on the skin of the guinea pig.

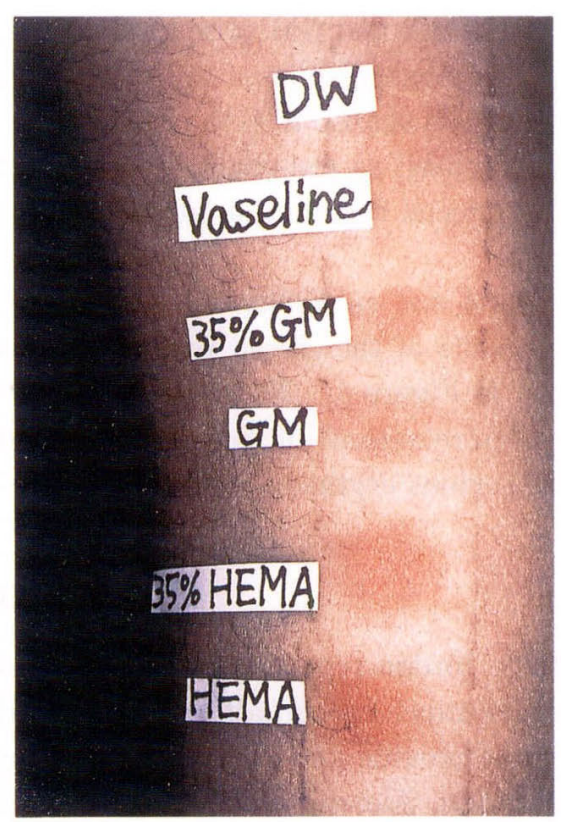

Fig. 4 This shows the reaction on a human arm sensitized by 2 HEMA and GM. 
Table 8 Methacrylate derivatives used for elicitation

\begin{tabular}{cllllll}
\hline & \multicolumn{9}{c}{ Mean response } \\
\cline { 2 - 8 } $\begin{array}{c}\text { Concentration } \\
\text { (\%) }\end{array}$ & \multicolumn{2}{c}{ 2-HEMA } & \multicolumn{2}{c}{ GM } & \multicolumn{2}{c}{ MA } \\
\hline 10 & $24 \mathrm{~h}$ & $48 \mathrm{~h}$ & $24 \mathrm{~h}$ & $48 \mathrm{~h}$ & $24 \mathrm{~h}$ & $48 \mathrm{~h}$ \\
25 & 0 & 0 & 0 & 0 & 1.3 & 1.3 \\
50 & 0 & 0 & 0 & 0 & 3.3 & 3.3 \\
100 & 0 & 0 & 0 & 0 & 7.0 & 7.0 \\
\hline
\end{tabular}

Skin reaction was judged after 24 and 48 hours.

Table 9 Result of closed patch test on humans

\begin{tabular}{lrc}
\hline & & After 3 days \\
\hline 2-HEMA & $35 \%$ & $(++)$ \\
& $100 \%$ & $(++)$ \\
GM & $35 \%$ & $(+)$ \\
& $100 \%$ & $(+)$ \\
Vaseline & & $(-)$ \\
Distilled water & & $(-)$ \\
\hline
\end{tabular}

GM. Based on these findings, the optimum concentrations for sensitizing guinea pigs were $0.2 \%$ for 2 -HEMA and $0.5 \%$ for GM.

2) Determination of optimum concentrations of 2-HEMA, GM, and MA for elicitation. The results obtained with the various challenge concentrations are shown in Table 8.

2-HEMA and GM produced skin reactions in guinea pigs only at concentrations of 100 \%. The mean responses to 2-HEMA were 5.0 and 2.4 after 24 and 48 hours, respectively. The mean response to GM was 1.8 after both 24 and 48 hours. In contrast, the response to MA increased as the challenge concentration increased from $10 \%$ to $100 \%$. Furthermore, MA produced rubefaction at all of the concentrations tested.

\section{The patch test on humans}

The results of the closed-patch test carried out on a possibly 2-HEMA-allergic dentist are shown in Figure 4. The reading was performed following ICDRG criteria on Day 3 (Table 9). Concentrations of 35\% 2-HEMA, 100\% 2-HEMA, 35\% GM and 100\% GM were seen to cause serious erythemic papules.

\section{DISCUSSION}

In 1975, Jordan reported that one or more of the acrylate components used in commercial adhesive tapes caused allergic contact dermatitis, and suggested that methyl methacrylate may not provide and adequate screening test for the many acrylates used commercially ${ }^{19)}$. In addition, Alexander et al. concluded that a methyl methacrylate liquid monomer is a sensitizer and can cause an allergic contact-type eczematous reaction of the skin and the oral mucous tissue ${ }^{20)}$. Estlander et al. reported that acrylic monomers in denture base materials could cause dermatitis on the hands of dental technicians. The researchers noted that 
repeated hand-washing caused dryness and chapping, and considered that these conditions may promote the penetration of acrylic monomers into the skin and cause irritation ${ }^{21)}$.

When methacrylate derivatives are used as composite resins, it is possible for the operator's fingertips and the patient's lips to come into contact with the resins. Nathanoson et al. suggested that dentists who use composite resins should be aware of the possibility of delayed extraoral manifestations of hypersensitivity to those materials and of the need for careful management of patients being treated with the resins. A possible sensitizer in this case could be the epoxy component bisphenol-A, a material used in the production of the composite matrix. It was recommended that, during the procedure, the involved teeth be isolated with a rubber dam that covers all of the mucogingival tissues ${ }^{22}$. Since maximization test has been widely used for evaluating to produce allergic reaction, we examined possible allergenic effects of dentin primers by employing chemicals of their abilities this test.

The results of the present study indicate that methacrylate derivatives used as dentin primers (2-HEMA and GM solutions) cause type IV delayed allergic reactions. In particular, 2-HEMA produced sensitization over a wider range of concentrations than GM. MA produced both simple irritation and delayed hypersensitivity. 2-HEMA has been shown to penetrate skin tissue more readily than $\mathrm{GM}^{13}$. Therefore, 2-HEMA may bind to proteins in skin cells. Clemmensen reported that the sensitizing potential of 2-HEMA preferentially stimulates suppressor cell function ${ }^{23)}$. Although guinea pigs were sensitized with 2-HEMA or GM, only $100 \%$ challenge solutions elicited symptoms of irritation.

In accordance with the present experiments, the volunteer who had experienced rubefaction and pruritus only at the tips and sides of his fingers also had a positive reaction to the patch test conducted with dentin primers. The volunteer showed positive reactions to both concentrations (35\%, 100\%) of both HEMA and GM. Although guinea pigs reacted only to $100 \%$ HEMA and GM; the volunteer was more sensitive to these dentin primers than the animals. Therefore, there might be a good correlation between the guinea pig maximization test and the human patch test. These symptoms may have been affected by local Langerhans' cells. 2-HEMA is widely used in composite resins and bonding agents. Kanerva et al. reported that allergic contact dermatitis in response to composite resins could be due to the resins' aromatic and aliphatic epoxy acrylates. The researchers suggested that dental personnel should be aware of the risks associated with dental composite resins, and should use no-touch techniques and protective gloves ${ }^{24)}$.

\section{CONCLUSION}

In this sudy, we determined the optimum concentrations of dentin primers for sensitizing guinea pigs. 2-HEMA caused sensitized delayed allergic reactions at all of the concentrations tested. Delayed allergic reactions are often found with new dental monomers. The present findings, together with those of our previous studies, may be useful in further experimental studies of such primers. 


\section{REFERENCES}

1) Itoh, K., Hashimoto, K. and Wakumoto, S.: Effect of GLUMA concentration on adhesion on dentin, Japan J Conserv Dent. 28 (3) : 895-901, 1985. (in Japanese)

2) Chiba, M., Hasegawa, T., Shimizu, A., Maeda, Y., Itoh, K. and Wakumoto, S. : Effect of 35\% HEMA treatment on the adhesion of resin material-Evaluation of application time-, Japan J Conserv Dent 29 (6) : 1573-1576, 1986. (in Japanese)

3) Itoh, K. and Wakumoto, S. : Momentary pretreatment by $35 \%$ HEMA solution combined with five marked bonding agents, Dent Mater J 6 (1) : 28-31, 1987.

4) Chigira, H., Manabe, A., Itoh. K., Wakumoto, S, and Hayakawa, T. : Efficacy of glyceryl methacrylate as a dentin primer, Dent Mater J 8 (2): 194-199, 1989.

5) Manabe, A., Katsuno, K., Itoh, K., Wakumoto, S. and Miyasaka, T. : Bonding efficacy of erythritol methacrylate solution as dentin primer, J Dent Res 70 (9) : 1294-1298, 1991.

6) Waegemaekers, T., Seutter, E., Den, Arend, J. A. C. J. and Malten, K. E. : Permeability of surgeon's glove to methyl methacrylate, Acta Orthop Scand 54: 790-795, 1983.

7) Pegum, J. S. and Medhurst, F. A.: Contact dermatitis from penetration of rubber gloves by acrylic monomer, Br Med J 2 : 141-143, 1971.

8) Mathias, C. G. T., Turner, M. C. and Maibach, H. I : Contact dermatitis and gastrointestinal symptoms from hydroxyethylmethacrylate, Br J Dermatol 100 : 447-449, 1979.

9) Hayakawa, R., Takeuchi, Y. and Kojima, S.: Occupational allergic contact dermatitis due to 2hydroxy-ethyl methacrylate, Skin Res 31 (7) : 17-23, 1989. (in Japanese)

10) Malten, K. E. and Bende, W. J. M. : 2-Hydroxy-ethyl-methacrylate and di-and tetraethylene glycol dimethacrylate: Contact sensitizers in a photoprepolymer printing plate procedure Contact Dermatitis 5: 214-220, 1979.

11) Van der Walle, H. B., Klecak, G., Geleick, H.and Bensink, T: Sensitizing potential of 14 mono (meth) acrylates in guinea pig, Contact Dermatitis 8:223-235, 1982.

12) Manabe, A., Hasegawa, T., Chigira, H., Itoh, K. and Wakumoto, S.: Morphological changes of rabbit skin by application of dentin primer, Dent Mater J 9 (2) : 147-152, 1990.

13) Katsuno, K., Manabe, A., Nakayama, S., Tachikawa, T., Itoh, K. and Wakumoto, S. : Morphological change in rat skin resulting from the application of dentin primer, Dent Mater $J 10$ (1): 72-78, 1991.

14) Katsuno, K., Manabe, A., Hasegawa, T., Nakayama, S., Itoh, K., Wakumoto, S. and Hisamitsu, H.: Possibility of allergic reaction to dentin primer-Application on the skin of guinea pigs-, Dent Mater J 11 (1) : 77-82, 1992

15) Katsuno, K., Manabe, A., Itoh, K., Hisamitsu, H., Wakumoto, S., Nakayama, S. and Yoshida, T.: A delayed hypersensitivity reaction to dentine primer in the guinea pig, J Dent 9 (2) : 147-152, 1990.

16) Magnusson, B. and Kligman, A. M. : Allergic contact dermatitis in the guinea pig, Springfield, Illinois : Thomas, 1970, pp. 102-123.

17) Shelley, W. B.: The patch test, JAMA 200 (10) : 874-878, 1967.

18) Alexander, A. and Fisher, M. D. : Contact dermatitis, 3th ed., Lea \& Febiger, Philadelphia, 1986, pp. 25-26.

19) Jordan, W. P.: Cross-sensitization patterns in acrylate allergies, Contact Dermatitis 1: 13-15, 1975.

20) Alexander, A., Fisher, M. D. and Woodside, N. Y. : Allergic sensitization of the skin and oral mucosa to acrylic denture materials, JAMA 156 (3) : 238-242, 1954.

21) Estlander, T., Rajaniemi, R. and Jolanki, R. : Hand dermatitis in dental technicians, Contact Dermatitis 10 : 201-205, 1984.

22) Nathanson, D. and Lockhart, P.: Delayed extraoral hypersensitivity to dental composite material, Oral Surg. OralMed. Oral Pathol. 47 (4) : 329-333, 1979.

23) Clemmensen, S. : Sensitizing potential of 2-hydroxyethylmethacrylate Contact dermatitis 12: 203-208, 1985.

24) Kanerva, L., Estlander, T. and Jolanki, R. : Allergic contact dermatitis from dental composite resins due to aromatic epoxy acrylates and aliphatic acrylates, Contact Dermatitis 20: 201-211, 1989. 


\title{
本号揭載論文の和文抄録
}

\author{
接着性モノマーの NMR 研究 \\ 5 -メタクリロイルアミノサリチル酸の ${ }^{13} \mathrm{C}-\mathrm{NMR}$ スペクトルの \\ 完全帰属と分子幾何学研究 \\ 伊藤 茂, 藤沢盛一郎 ${ }^{1}$ \\ 東京医科歯科大学医用器材研究所化学部門 \\ ${ }^{1}$ 明海大学歯学部口腔診断学講座
}

6 個の四級炭素をもつ 5-メタクリロイルアミノサリ チル酸 (MASA) の ${ }^{13} \mathrm{C}-\mathrm{NMR}$ スペクトルをDEPT スペ クトルならびに $\mathrm{CH}-\operatorname{cosy}$ や $\mathrm{HMBC}$ 等の 2 次元 $\mathrm{NMR}$ スペクトルの解析により完全帰属した. MASA の ${ }^{13} \mathrm{C}$ -NMR 化学シフト值のコンピュータプログラムによる
経験的な予測は C 1 と 2 '位 $\mathrm{CH}_{3}$ の值を除いて観測値 と比較的よく一致した. 2 次元 NMR を用いた核オー パーハウザー効果の測定・解析と分子軌道計算結果の比 較により MASA の側鎖部分の立体配置は極性および非 極性雾囲気下において異なることが示唆された。

\section{チタン研磨面の污染}

宮川 修, 渡辺孝一, 大川成剛, 金谷 貢, 中野周二, 小林正義 ${ }^{1}$

新潟大学歯学部歯科理工学講座

1新潟大学分析センターEMX 室

チタン研磨面の污染について検討した，研磨装置によ り, $\mathrm{SiC}$ 耐水研磨紙を用いて水冷下で研磨し, 研磨面の元 素分析, X 線回折, 硬さ測定を行った. 10〜 30 $\mu \mathrm{m}$ の大 きさの污染物様のものが研磨面全体に観察された. そこ での Ti の見かけの濃度は約 $10 \%$ 低下し, Si とOの濃度 が高かった: $\mathrm{Si}$ の結合状態は SiC または Ti-Si 化合物の
それに似ていた。 $\mathrm{O}$ は固溶酸素として存在し，研磨面を 硬化させた. 污染物は非晶質か, あるいは非常に薄いこ とが示唆された.このようなチタンの污染は, その硬さ とも無関係ではないが，研磨材との何らかの反応による と考えられる.

モルモットを用いた各種デンティンプライマーによる接触性皮膚炎の検討 勝野和之, 真鍋厚史, 伊藤和雄, 中村吉宏, 和久本貞男, 久光 久, 吉田武美 ${ }^{1}$

昭和大学歯学部歯科保存学第 2 講座 ${ }^{1}$ 昭和大学楽学部毒物学教室

コンポジットレジンの象牙質窩壁適合性を改善する目 的で適用されるデンティンプライマーやボンディング材
の多くは, 2-hydroxyethyl methacrylate (HEMA) が配 合されている.しかしながら, 我々はこの HEMA を長期 
間手指に反復接触させることにより発赤, 腫脤を伴う匴 痒感に遭遇することを報告しており，さらに多くの研究 者らは，この症状が遅延型アレルギーであることを報告 している.今回の研究目的は, モルモットを用い, HEMA 及び試作デンティンプライマーとして用いられている Glyceryl methacrylate (GM) 水溶液及びメタクリル酸 の至適感作濃度, および至適誘発濃度を検討するととも に実際に感作されていると思われる患者に，パッチテス
トによって感作源を確認することである。その結果，至 適感作濃度は, HEMA，GM ともに 0.2 から $0.5 \%$ の濃 度でほとんどの動物が感作され, 誘発濃度はメタクリル 酸以外は $100 \%$ のであった。またパッチテストでは HEMA と GM に交差反応が認められた。このことによ り，ヒ卜に対する感作濃度は非常に低濃度であることか ら，臨床的にラバーグラブを装着し，極わずかな接触も 回避することが重要であると思われる。

\section{電気化学的析出したリン酸カルシウム塩の形態に及ぼす温度の影響 \\ 伴 清治，丸野重雄 ${ }^{1}$ ，原田敦史，服部雅之， 成田潔治，長谷川二郎 \\ 愛知学院大学歯学部歯科理工学講座 \\ 1名古屋工業大学工学部電気情報工学科}

$\mathrm{NaCl}, \mathrm{K}_{2} \mathrm{HPO}_{4}$ およひ $\mathrm{CaCl}_{2}$ ・2 $\mathrm{H}_{2} \mathrm{O}$ を含を電解液を $4^{\circ} \mathrm{C}$ から $92^{\circ} \mathrm{C}$ に保持し, リン酸カルシウム塩をチタン 基板上に電気化学的に合成した。走查電顕観察より, $4{ }^{\circ} \mathrm{C}, 22^{\circ} \mathrm{C}, 37^{\circ} \mathrm{C}$ での析出物は顆粒状であり, $52^{\circ} \mathrm{C}$ から $92^{\circ} \mathrm{C}$ での析出物は針状であった。針の幅と長さは電解液 温度の上昇に伴い大きくなった。電子線回折, フーリエ
赤外分光分析， X 線回折を用いた状態分析の結果，顆粒 状析出物は結晶性の低いリン酸カルシウム塩であり，針 状析出物は $\mathrm{c}$ 軸方向に配向した炭酸アパタイトであると 同定された。結晶性は電解液温度の上昇に伴い高くなっ たが, 002 面の配向度は電解液温度の上昇に伴い $82^{\circ} \mathrm{C} ま$ では増加し $92^{\circ} \mathrm{C}$ ではわずかに減少した。

\section{谷 千尋，真鍋厚史，伊藤和雄， 和久本貞雄, 久光 久 \\ 昭和大学歯学部 \\ 歯科保存学第二講座}

象牙質面に対するデンティンボンディング材の接触角の計測

試作デンティンクレンザーおよびプライマーを用いて 象牙質処理を行った後の象牙質平面の濡れ性の変化を， 象牙質面上に滴下されたボンディング材および標準試薬 の接触角を計測し, 各々処理平面の表面自由エネルギー を算出することにより検討した。 その結果, EDTA 処理 後の wettability は研削面に比較して一旦低下し, その 後プライミング処理をおこなうと市販デンティンボン ディング材は滴下直後に象牙質面に急激に拡散し, con- tact angle は計測不可能となった。今回用いた試作デン ティンプライマーは, HEMA 水溶液を除いて象牙質円 柱窝洞内に填塞された市販可視光線重合型コンポジット レジンのコントラクションギャップの形成を完全に阻止 しうる，優れた粘着性改善効果を示すことが確認されて いるが，その作用機序は象牙質面の表面活性を効率的に 改善することによるものと考えられた。 